\title{
LIMITATION VOCABULARY CAN BE ONE OF FACTOR THE STUDENTS DO NOT WANT TO SPEAK ENGLISH
}

\author{
Rizka Dinda Amalia', Anita Anggraeni ${ }^{2}$ \\ IKIP Siliwangi \\ ${ }^{1}$ rizkadindaamalia@student.ikipsiliwangi.ac.id, ${ }^{2}$ anitaenglish26@gmail.com
}

\begin{abstract}
English is an International language that is used as an instrument to communicate. As a foreign language it is quite normal if English difficult to learn, because the way to write and read or speak English language is dissimilar whereas in Indonesian language the way to read or speak and write it is the same. Same as student in one of Junior High school in Lembang, some of them do not want to speak English language especially in from of the class. The author guest one of the factor students do not want to speak English is limitation vocabulary. In this article the author try to know is it true that limitation vocabulary is one of factor student do not want to speak English ? To answer that question, the author use qualitative method through questionnaire and interview for second grade student. The result finding that many factor student do not want to speak English one of them is limitation vocabulary, the student said that is no easy to memorize a lot of vocabulary, when they memorize it the feel bored. To make the student do not feel bored the author suggest to use some games in the class to make the student more attractive.
\end{abstract}

Keywords: Vocabulary, Factor, Speaking

\section{INTRODUCTION}

English is an International language that is used as an instrument to communicate has four skills: listening, speaking, reading and writing. As a foreign language it is quite normal if English difficult to learn, because the way to write and read or speak English language is dissimilar whereas in Indonesian language the way to read or speak and write it is the same. Based on writer's observation and interview result from some of the students in one of school in Junior High School in Lembang they said that it was not easy to speak English, because English language has different characteristic compared to bahasa Indonesia. In English they need to learn how to write and how to speak correctly, in other hand what they write the word has different way with how they read and speak the word and also they have problem with their vocabulary which means they have limited vocabulary. They stated that to remember a lot of vocabulary is hard. However, in order to be able to speak, students should study and memorize vocabulary. According (Bai, 2018) very important for student to accurate vocabulary learning strategies. Using accurate vocabulary can increase students speaking skill also. Based on (Nunan, 1995) as cited in (Djahimo, 2018) speaking skill is in a lot of tests, people still consider that the skill to speak in the target language is the way to quantify whether or not learners are doing well in their learning process.

Speaking skill is one of important skill for EFL to communicate, this statement supported by (Atkinson, 1985) in (Menggo, 2018) Speaking is viewed as a skill in delivering information, ideas or concepts to the interlocutor. Darmadi(2015) as cited in Parmawati \& Inayah (2019) defines speaking as a productive skill that can be observed directly and empirically. Speaking skill can make the learners easier to communicate, even though some of EFL learners thought that speaking skill is difficult. Based on Brown et al., 1983 in (Djahimo, 2018) several EFL 
students assume that being able to speak high-quality English is not a simple practice because speaking is considered the hardest skill to be mastered. Without speaking skill the learners cannot practice their language when communication. It is important in teaching and learning process to know the students factor or students problem in learning process, this statement supported by (Ruan \& Agency, 2018) this is an necessary starting point that has to be applied by EFL teachers and/or

lecturers in education speaking. One at a time to build students speak excellent, confident, and accurate English, teachers have to truly be aware of the cause of problems their students meet in the teaching and learning process.. A lot of factor that student do not want to speak English. Such as main factor below : performance conditions, affective factors, listening ability, topical knowledge, and feedback during speaking activities (Tuan \& Mai, 2015) os cited in (Djahimo, 2018) :

1. The problem of performance conditions is the first factor student do not want to speak. Different condition can give the student different result.

2. Effective factors is the second main issue dealing with students' affective domain. Variety aspects have been integrated in affective factors but the most general ones are anxiety, motivation, and self-confidence (Krashen, 1982).

3. As the third factor how listening and speaking skill relate to each, identify listening ability. One has to be competent to accept well (trough listening) one at a time to create well again (trough speaking) (Doff, 1998; Shumin, 1997). This describes that speaking and listening is connecting. If speakers cannot understand what they are listening to, then there will be no communication as they want, not be able to respond.

4. Topical knowledge. This factor is important also like the other factor, because without good at basic knowledge the student cannot be active in teaching and learning process, how can the student be active student if they do not know what the lesson is. As we know English language has three elements, there are : pronunciation, vocabulary and grammar, that means vocabulary is important for student in learning English. This statement supported by (Susanto, 2017) that vocabulary skill is often believed as a critical part of foreign language learners as limited vocabulary in a second language and has realized that the attainment of vocabulary is important for successful foreign language apply and plays an important character in the formation of complete speaking skill and writing skill. It is almost impossible to speak without a word of vocabulary. Based on (Siliwangi, 2019) Vocabulary participates a important function for language abilities additionally vocabulary is central to learning a new foreign language at main level Cameron (2001). According to Alqahtani (2015) in (Hussain, 2018) said that Vocabulary means words that we apply toward communicate efficiently into speaking (expressive vocabulary) and into listening (receptive vocabulary).

5. Feedback during speaking activities as the last factor. This factor is quite important because without feedback may the student cannot be spirit in the class, the teacher can give them point or value to make the student active. This condition can make the student more attractive and has motivation to learn more. And we also give them good feedback if their make a mistake such as give them the right answer. If the teacher give a wrong feedback when the student make a mistake maybe the student will be stop to be attractive student. This statement supported by (Harmer, 2001; Baker \& Westrup, 2003) that if the teacher decide to give feedback after the presentation, students might forget about the errors and/or mistakes they've committed in their presentation. In this case, teachers have to be very careful to decide when the right time to give feedback to students is, otherwise and this will make them stop talking. 


\section{METHOD}

In this research, the sample of 8th grade in one of junior high school in Lembang must be answer the questionnaire and also the interview. To get more information the writer will give questionnaire and interview some of 8th grade students. The questions that will be asked during the interview are almost the same as those answered on the questionnaire, only added by stating the reasons for the answers mentioned, and some questions that can be asked situational. In this article the researcher use descriptive qualitative method. According to Alwasilah (2002) in (Ibrohim et al., 2019) descriptive research explains identifies a set, mistake and phenomenon by which the method commonly used to quantify three things, they are: 1) the reality and delivery of various behaviour or characteristics that happen naturally; 2) regularity happens in nature; 3) connection and magnitude relationship that may be present among the characteristics, bahaviour, events, or phenomena of concern to the research. As confirmed before, the goal in this study is to make sure if limitation vocabulary factor can be a reason for student don't want to speak English language especially in front of the class.

\section{RESULTS AND DISCUSSION}

\section{Results}

To know the students factor the researcher focus on two steps, there are :

1. Questionnaire

To discover the student's statement, the student were allowed to choose one of the option : S (Setuju) dan TS (Tidak Setuju). According to student's answer the researcher got the result as follows :

Table. 1

\section{Result of Questionnaire.}

\begin{tabular}{llll}
\hline \multirow{2}{*}{ No } & \multirow{2}{*}{ Pernyataan } & \multicolumn{2}{l}{ Total of Students Answer } \\
\cline { 2 - 4 } & S & TS \\
\hline 1 & Saya menyukai mata pelajaran bahasa Inggris. & 13 & 10 \\
\hline 2 & $\begin{array}{l}\text { Saya merasa kesulitan dalam berbicara, membaca, } \\
\text { mendengarkan bahasa Inggris. }\end{array}$ & 18 & 5 \\
\hline 3 & $\begin{array}{l}\text { Saya senang berbicara bahasa Inggris walaupun saya } \\
\text { belum fasih }\end{array}$ & 8 & 15 \\
\hline 4 & Bahasa Inggris itu penting untuk dipelajari & 0 & 23 \\
\hline 5 & Saya merasa bahasa Inggris itu adalah bahasa yang sulit. & 14 & 9 \\
\hline 6 & $\begin{array}{l}\text { Kosa kata adalah salah satu kesulitan yang saya hadapi } \\
\text { dalam mempelajari bahasa Inggris }\end{array}$ & 20 & 3 \\
\hline 7 & $\begin{array}{l}\text { Saya menyukai bahasa Inggris ketika saya menguasai } \\
\text { kosa kata bahasa Inggris. }\end{array}$ & 23 & 0 \\
\hline 8 & $\begin{array}{l}\text { Saya selalu menanyakan kepada guru jika saya } \\
\text { menemukan kosakata yang tidak saya mengerti }\end{array}$ & 12 & 11 \\
\hline 9 & $\begin{array}{l}\text { Saya selalu mencari arti kata dalam bahasa Inggris yang } \\
\text { saya tidak mengerti }\end{array}$ & 10 & 13 \\
\hline 10 & $\begin{array}{l}\text { Saya selalu diam ketika menemukan kosakata yang tidak } \\
\text { saya mengerti }\end{array}$ & 9 & 10 \\
\hline $\begin{array}{l}\text { Jika saya mengerjakan soal bahasa Inggris, saya suka } \\
\text { menebak arti dari kosakata berdasarkan gambar atau } \\
\text { kalimat }\end{array}$ & 13 & 10 \\
\hline
\end{tabular}




\begin{tabular}{llll}
\hline 12 & $\begin{array}{l}\text { Saya tidak akan menjawab soal yang kosa katanya tidak } \\
\text { saya ketahui }\end{array}$ & 13 & 10 \\
\hline 13 & $\begin{array}{l}\text { Saya senang belajar kosakata dengan berbagai macam } \\
\text { permainan secara individu }\end{array}$ & 18 & 5 \\
\hline 14 & $\begin{array}{l}\text { Saya senang belajar kosakata drengan berbagai macam } \\
\text { permainan secara berkelompok }\end{array}$ & 20 & 3 \\
\hline
\end{tabular}

2. Interview

This step is given after the questionnaire, the researcher interview 5 students from second grade. The first student is the most clever in the class, the third is mediocre student, the last student is the student that has not enough in English lesson. The answer are :

1) Student $1:$ He said, he like learning English language because English is international language. He thinks English is not too difficult and also not too easy. The obstacle when he learning English is vocabulary. because a lot of vocabulary that he must to remember. He like speak English when the teacher give him point for every single answer even though his English is not good but it can be his motivation to get the best score in English lesson. Sometimes he fall silent when she do not know the vocabulary or the meaning, but the most important he try to speak up. He like learn vocabulary by individual game, using that way he can know the ability he has.

2) Student $2:$ She said that she like English because when she can be a master in English language she can communicate with other people when she goes to another country. She thinks that English is a bit difficult because the way to write and read English language is dissimilar whereas in Indonesian language the way to read and write it is the same. She said she can follow what the teacher said when the teacher give five vocabulary at the end by herself, but when the practice in front of her friend especially in front of the class she cannot remember the vocabulary, she also cannot speak clearly, because she afraid she will make a lot of mistakes. She like study vocabulary using grouping game, because she can discussed with her friend and practice together, with that way she can correct each other when she try to speaking.

3) Student $3:$ He said, he do not like English, because he is Indonesian people that means he loved to use Indonesian language. in his opinion English is complicated, there a lot of meaning in one word that make him confused and difficult to remember. The hardest in English language is when he must to remember vocabulary. That's why he do not want to speak up with English in the class. He like learning vocabulary by grouping game, because he can get help from his friend.

\section{Discussion}

Based on the table and the interview above, the result can answer the questions that many factor the student do not want to speak English, there are : afraid to make a mistake, do not know the meaning of vocabulary, the way to write and the way to read is different, English is complicated language because one word has many meaning, difficult to remember a lot of vocabulary. It also can answer the second question in research that limitation vocabulary can be one of factor student do not want to speak English.

\section{CONCLUSION}

According to the result many factor can make the student do not want to speak English, one of them is limitation vocabulary, as we know vocabulary is important element in English, vocabulary is basic to speak English, without vocabulary the learners cannot use English 
language. for some student remembering vocabulary is difficult, because one word have many meaning that's why the learners has limitation vocabulary.

\section{ACKNOWLEDGMENTS}

Alhamdulillahirobbil 'alamin, the author say thank you especially to Allah SWT who has given the opportunity, health, and blessing, that make the author can finish this article well. Thanks for article supervisors who always support the author when conducting this research. Thanks for the husband, the parents, the siblings and friends who never stop giving the author motivation to finish this article. Thank you for one of Junior High school in Lembang for conceding permission so that the research can take place. The author also thanks to IKIP Siliwangi for giving the author opportunity to publish this article.

\section{REFERENCES}

Bai, Z. (2018). An Analysis of English Vocabulary Learning Strategies. Journal of Language Teaching and Research, 9(4), 849. https://doi.org/10.17507/jltr.0904.24

Djahimo, S. E. . (2018). Student anxiety and their speaking performance: teaching EFL to Indonesian student. International Journal of Social Sciences and Humanities, 2(3), 187195. https://doi.org/10.29332/ijssh.v2n3.235

Hudaya, A., \& Sadikin, I. S. (2019). The Effect of Aurasma Augmented Reality (AR) to Enhance Young Learners'vocabulary Mastery. PROJECT (Professional Journal of English Education), 2(6), 783-790.

Hussain, Z. (2018). the Effects of Ict-Based Learning on Students' Vocabulary Mastery in Junior High Schools in Bandung. International Journal of Education, 10(2), 149-156. https://doi.org/10.17509/ije.v10i2.7592

Ibrohim, A. T., Septianti, A., \& Sadikin, I. S. (2019). Students' Perception Toward Teaching English Vocabulary Through Total Physical Response (Tpr) Method. PROJECT (Professional Journal of English Education), 145. https://doi.org/10.22460/project.v1i2.p145-156

Menggo, S. (2018). English Learning Motivation and Speaking Ability. Journal of Psychology and Instructions, 2(2), 70. https://doi.org/10.23887/jpai.v2i2.15979

Parmawati, A., \& Inayah, R. (2019). Improving Students'speaking Skill through English Movie in Scope of Speaking for General Communication. Eltin Journal, Journal Of English Language Teaching In Indonesia, 7(2), 43-53. https://doi.org/10.22460/eltin.v7i2.p43-53

Ruan, X., \& Agency, P. (2018). Engagement and Negotiation : Exploring a Tertiary Female EFL Teacher 's Professional Agency in Her Career Development in. 4(3), 46-63.

Susanto, A. (2017). The teaching of vocabulary: A perspective. Jurnal Kata: Penelitian Tentang Ilmu Bahasa Dan Sastra, 1(2), 182-191.https://doi.org/10.22216/jk.v1i2.2136 